\title{
Modern processes of regional economic integration of Ukraine in the context of sustainable development
}

\author{
Vitalina Babenko, ${ }^{1,}$, Iryna Perevozova ${ }^{2}$, Maryna $\mathrm{Kravchenko}^{3}$, Marharyta $\mathrm{Krutko}^{4}$, and Dariia Babenko $^{5}$ \\ ${ }^{1}$ V.N. Karazin Kharkiv National University, International E-commerce and Hotel \& Restaurant Business Department, 4 Svobody Sq., \\ Kharkiv, 61022, Ukraine \\ ${ }^{2}$ Ivano-Frankivsk National Technical University of Oil and Gas, Entrepreneurship and Marketing Department, 15 Karpatska Str., Ivano- \\ Frankivsk, 76018, Ukraine \\ ${ }^{3}$ National Technical University of Ukraine "Igor Sikorsky Kyiv Polytechnic Institute", Management Department, 37 Peremohy Ave., \\ Kyiv, 03056, Ukraine \\ ${ }^{4}$ Kharkiv Petro Vasylenko National Technical University of Agriculture, Department of Accounting and Audit, 44 Alchevskikh Str., \\ Kharkiv, 61002, Ukraine \\ ${ }^{5}$ Simon Kuznets Kharkiv National University of Economics, Department of International Economics and Management of Foreign \\ Economic Activity, 9A Nauky Ave., Kharkiv, 61166, Ukraine
}

\begin{abstract}
Ensuring economic sustainable development in difficult political and economic conditions is one of the priority tasks for Ukraine. It is forced to reorient the vector of foreign economic cooperation, in particular, the integration formations of the European Union. The aim of the article is to study the development of the processes of regional integration of Ukraine to ensure sustainable economic development, as well as determine the priority direction of its regional integration. The role of Ukraine in the processes of economic integration at the present stage of development is analyzed. Based on the analysis of the current state and development features of the EU and Ukraine, the prospects for the activation of its participation in integration processes, namely entry into the EU, are substantiated. By analysis, the domestic market of Ukraine, the general state of development and its place in the world market are investigated. As a result, the features and barriers of Ukraine's European integration and ways to address them were identified, as well as an attempt was made to identify the main areas of cooperation and ways to improve economic relations between Ukraine and the EU.
\end{abstract}

\section{Introduction}

"Ensuring the sustainable development of mankind is the most significant problem facing the world community". Such a statement was made in 1987 by the UN General Assembly [1]. And today, such a statement has not lost its relevance - the concept of sustainable development is constantly actively discussed by world leaders. The Sustainable Development Goals is a kind of call to action emanating from all countries - poor, rich and moderately developed. States recognize that poverty eradication measures must be taken by integration efforts to boost economic growth and address a range of issues in the fields of education, health, social protection and employment, as well as combating climate change and environmental protection, in particular economic stability.

According to the UN Development Program [2], in the context of economic sustainable development of the countries of the world, the following strategic objectives are set:

- To achieve increased effective international cooperation, including by paying special attention to the processes of regional integration.
- Support the economic growth of countries, including and on the basis of trade and economic ties between integration associations (in particular, the growth of gross domestic product at a level of at least 7 percent per year in the least developed countries).

- Increase the assistance provided by the Aid for Trade initiative to developing countries, especially the least developed countries, including through the Expanded Integrated Framework for the provision of technical assistance in trade to the least developed countries.

Having found itself in difficult political and economic conditions, Ukraine is forced to reorient the vector of foreign economic cooperation. In this regard, she is trying to strengthen ties, in particular, the integration formations of the European Union and intends to become a member.

Thus, for sustainable economic development, peaceful coexistence and effective international cooperation of Ukraine it requires determining the priority direction of integration, in particular, the main direction of Ukraine's foreign policy is Euro-integration.

\footnotetext{
* Corresponding author: vitalinababaenko@karazin.ua
} 


\section{Literature review}

Over the past half century, the concept of "integration" has become an important economic category in world politics and international relations. The focus was on such important problems of our time as ensuring conflict-free coexistence of states and developing effective cooperation, the functions and fate of a modern state, and the interaction of politics and economy. One of the consequences of globalization is the spread of regionalism, which should be considered not only as a tool to increase the intensity and efficiency of economic ties between neighboring countries, but also as a mechanism for collective protection of the interests of the countries of the region in the face of increased competition and instability in the world. The issues of optimizing the processes of founding and functioning of integration entities and the possibility of participating countries getting the maximum results from the association are constantly in the field of vision of scientists and politicians.

The consequence of globalization and integration processes was the creation and functioning of such entities as the EU, ASEAN, MERCOSUR, NAFTA, the CIS and others. A lot of research has been devoted to the concept of regional integration, in particular, [3-7]. Scientists not only explored the issue of regional integration processes, but also formulated the concept and identified the stages and forms of development of this process on a global scale.

Among foreign scholars, one can recall the work of Almira Enders, Zeno Enders, Mathias Hoffmann [8] some others who study regional integration processes in the current development of the geopolitical situation and its transformation [9]. Scientists study in detail both the existing regional integration and the new ones that arise under the influence of new factors and have new conditions and development goals, as, for example, Abdullah R. Alotaibi, Anil V. Mishra [10] study the associations of Brazil, Russia, India, China, South Africa (BRICS).

The issues of regional integration are especially relevant for Ukraine, since it seeks to integrate into the European economic and political community and paid a rather high price for this desire. The study used the research of domestic scientists: S. Didenko [11], O. S. Kvasha, A. V. Synyakova [12], S. V. Marynina [13], M. I. Nazarov [14], A. A. Ryeznikova [15], T. V. Shcherbyna [16].

The work [11] analyzes the functional structure of globalization as a driving force of world regional economic integration processes, indicating the prerequisites and results of the interaction of this sphere. The basic theories of regional integration are structured and modern regional associations of the world are classified using models of integration processes. A. S. Kvasha offers a scientific approach to determining the main parameters, areas of activity and principles of Ukraine's integration into the European economic, political and sociocultural space, forms the main basis for European integration processes in the economy regarding the economic part of the Association
Agreement between Ukraine and the EU. In the work of S. V. Marinina, it was proved that regional integration processes have become the most influential factor in the development of world economic dynamics and an objective process of establishing sustainable economic ties and the division of labour of national economies, both close in terms of economic development and having significant differences in their development [13]. T. Shcherbina suggests looking at the processes of development of regional economic integration as a continuation and deepening of international cooperation within the framework of the concept of strategic partnership, in fact creates the ground for merging and interpenetration of economic systems, and is also able to explain the motives of international cooperation of countries [17].

However, this issue requires further consideration and study, since integration processes are constantly changing and developing.

\section{Analysis of the development of regional integration processes in a globalized world}

International economic relations have always had a great influence on the development of each country. Now all the countries of the world are somehow involved in the world economy. Therefore, the belonging of a country to one or a group of countries, an integration association, is of particular importance. Now in the era of changes in economic geography, namely: the transfer of priority from agriculture to industry and services, regional integration has the opportunity to strengthen the country's development in the system of international economic relations.

The development of integration processes in the modern system of international economic relations has become an objectively logical result of the growth in the movement of goods and factors of their production between different countries, which required the creation of more reliable supply chains between countries and the removal of numerous obstacles to international trade and the movement of factors of production. Interstate integration associations and multilateral political agreements have become a way to resolve many issues and solve international problems.

High rates of development of the global economy impose increased requirements on national farms, significant reserves of growth of which are laid in the sphere of integration.

According to A. Holikov's definition, the most important goal and result of regional integration is to increase the efficiency of using national potentials through mutually beneficial pooling of efforts and resources in solving problems of economic growth [7].

However, world experience shows that the advantages of regional integration in a certain way are manifested only if a comprehensive study of this process, strategy and tactics of its implementation. Otherwise, the positive effect of the transformation may be negligible. 
Understanding regional integration as a manifestation of globalization gives reason to believe that the underlying driving force of such integration is the desire of participating countries to a higher level of development and to fall into a different level of international economic relations than the one to which they would objectively belong without such interaction. So in the current geopolitical situation, it is precisely regional integration associations that can cause global changes and stimulate development [6].

Researcher of integration processes Yakubovskiy believes that "the integrity created by regional integration is the integrity of a group of factors acting together in the process of globalization [3]. Therefore, this formulation is valid: regional integration is a model of conscious and active participation of a group of countries in the processes of ranking the world due to globalization, which confirms. As a result of trade relations, countries strive to increase efficiency and productivity, which is why the fact of unification into regional integrations is important for increasing rank in the system of international economic relations in the context of globalization changes" [4]. He created a scheme by which integration processes take place in the global world. First, there are prerequisites for the creation of integration processes, such as:

- similarity of levels of economic development of integrating countries;

- territorial proximity of states;

- common economic and other problems;

- demonstration effect;

- the domino effect (countries that are outside the bloc are developing worse, they are beginning to strive to join regional integration).

The main results of regional integration are:

- synchronization of the processes of economic and social development of countries;

- convergence of the importance of macroeconomic development indicators;

- deepening the interdependence of economies and the integration of countries;

- GDP growth and labour productivity;

- growth in production, cost reduction;

- formation of regional trade markets.

The concept of regional integration is formulated has a certain scientific novelty.

Firstly, a broader view is being made of the extremely dissimilar integration processes taking place in various regions of the world. Now all regional associations are preparing instruments of economic determinism, the main of which is the famous Bela Balashi scale of 1961. According to it, integration rises from the free trade zone to the customs union, further develops into a common market, and then turns into an economic and monetary union. From this point of view, the North American Free Trade Agreement (NAFTA) is still at the initial stage, and the Association of Southeast Asian Nations (ASEAN) is only approaching it. However, the Southern Common Market (MERCOSUR) is at the second stage, and the Economic Community of West African States (ECOWAS) is moving to the third.
Therefore, according to this model there is no analysis of the goals of a country for cooperation [17].

Secondly, the new definition clarifies that integration is both a state and a process, provided that they are the current model. Political elites are not attracting their countries to integration associations in such a way as to intensify exchanges with their neighbors, as for a strategic perspective.

Thirdly, the proposed wording changes the concept of integration development indicators. Available methods for assessing the intensity of intra-regional exchanges, synchronizing fluctuations in macroeconomic indicators, disseminating supranational decision-making methods, and public support do not lose relevance, but turn into additional characteristics of integration.

According to T. Shcherbina, today modern international economic relations are characterized by rapid development of integration processes at the regional level, manifested in the creation of new groupings of countries and the expansion of existing ones. Since regional integration is most successfully and dynamically carried out by the efforts of the European Union (EU), the overwhelming majority of theories regarding the understanding of the features of these processes concern European integration [18].

The differences between the economies of a group of countries and the economies of an individual country are eliminated in the process of international economic integration and are characterized by the following:

- within one country, goods, services and labour move freely;

- goods, services, capital and labour that move from one region of a country to another remain within the framework of the system of laws of one country, including those that regulate economic relations;

- on the scale of a group of countries there are several currencies and central banks that regulate the circulation of money. In the regions of one country, one national currency is in circulation, which is regulated by the central bank;

- the international movement of goods, services and labour is the subject of special intergovernmental treaties and agreements, the provisions of which do not apply to economic relations operating within countries.

The reduction of these differences in their complete elimination is a process of international regional economic integration [19]. They can be eliminated only as a result of actions of countries or special international organizations. International economic integration can only be called an economic association, which is carried out by politically independent states and is voluntary.

Modern international economic integration is influenced by a number of factors of world development, among which the most significant are globalization and regionalization, which do not exclude but complement each other [20, 21]. Expanding, regional organizations are developing a mechanism of economic cooperation, which becomes the property of the world community at the global level [8]. 


\section{Determining the priority of regional integration for Ukraine in the context of sustainable development}

For Ukraine, there are only two possible options for global integration: European integration and regional integration. It is known that one of the leading and basic methods of self-determination of a country in modern times is participation in the integration process. However, Ukraine's integration policy has always been fuzzy and complex. This is due to the influence, on the one hand, of the European development model, and, on the other, of the non-European model of economic development. The non-European development model of Ukraine was membership in the EurAsEC, while the European one was in the EU.

As A. Reznikova notes, "an indisputable fact is that Ukraine belongs to European (Western) civilization. In addition, the priority of the European choice is due to the peculiarities of modern development, it is most evident among the EU countries, and is characterized by the deepening of globalization processes, the growing importance of the humanitarian sphere, high information technologies, post-industrial principles of social development, the increasing role of intellectual capital and management, social and humanitarian factors of economic progress, prioritization of the basic principles of sustainable development, which It is not only an economic upsurge, but also a fair distribution of its results, an increase in people's capabilities. Such approaches are fully consistent with the interests of Ukraine" [16].

The specifics of the formation of the geopolitical orientations of Ukrainian citizens is largely due to the fact that the country was at the epicentre of two integration waves - European and Eurasian, radically different in goals, conditions and nature. The inertia of the Soviet heritage, complex socio-political processes within the country, and powerful external influences were designated as citizens [23]. Under such conditions, the core of the supporters of the European integration course gradually formed and strengthened in Ukrainian society.

It is worth noting that since 2002 (the beginning of the sociological research of the Razumkov Center on this subject) the number of supporters of European integration constantly prevailed over its opponents. Russian aggression against Ukraine, which began in February 2014, radically influenced the picture of public sentiment.

Firstly, the attitude of Ukrainian citizens to the Russian Federation has fundamentally changed. In particular, the majority of respondents note the need to curtail or reduce contacts with Russia.

Secondly, the attitude of citizens of Ukraine to various integration vectors - European or Eurasian, was influenced by the Revolution of Dignity in December 2013 - January 2014, which defended and approved the European development course of Ukraine, as well as Russian aggression, which actually removed the Eurasian integration vector from the agenda for Ukraine.
Eurasian integration is now associated by citizens, primarily with the aggressor country.

If during the pre-war years (2011-2013) the share of supporters of Eurasian integration was about a third of the respondents, then in subsequent years the proportion of supporters of the Eurasian Economic Union (the former Customs Union of the CIS countries) fell - in 2015 to $15.9 \%$, and in 2017 it still fell to $7.8 \%$. Accordingly, the share of supporters of the European integration path has grown [23].

Thirdly, since 2014, there has been a tendency towards an increase in European sympathies in society. In December 2017, almost 60\% of Ukrainian citizens supported Ukraine's accession to the EU.

In addition, one of the directions of sustainable development for Ukraine is European integration, which means a way to modernize the economy and overcome technological backwardness. It is also a potential opportunity to receive foreign investments and the latest technologies, improve the competitive capabilities of domestic manufacturers, and access to world markets. An important aspect of European integration is trade with EU countries. At the present stage, the EU remains the main trading partner of Ukraine (Table 1).

Table 1. The main trading partners in export of Ukraine in 2018 [24].

\begin{tabular}{|c|c|c|c|}
\hline Countries & million dollars & \% to 2017 & $\begin{array}{c}\text { \% to common } \\
\text { volume }\end{array}$ \\
\hline Total, including: & 47339.9 & 109.4 & 100.0 \\
\hline Belarus & 1304.5 & 114.1 & 2.8 \\
\hline Egypt & 1557.1 & 85.0 & 3.3 \\
\hline India & 2175.9 & 98.7 & 4.6 \\
\hline Spain & 1370.0 & 108.7 & 2.9 \\
\hline Italy & 2628.8 & 106.5 & 5.6 \\
\hline China & 2200.3 & 107.9 & 4.6 \\
\hline Republic Moldova & 789.3 & 111.5 & 1.7 \\
\hline Netherlands & 1603.5 & 95.7 & 3.4 \\
\hline Germany & 2208.4 & 125.9 & 4.7 \\
\hline Poland & 3257.6 & 119.6 & 6.9 \\
\hline Russian Federation & 3654.1 & 92.8 & 7.7 \\
\hline Romania & 932.7 & 110.8 & 2.0 \\
\hline Saudi Arabia & 749.1 & 144.8 & 1.6 \\
\hline Slovakia & 864.2 & 131.7 & 1.8 \\
\hline USA & 1111.5 & 134.2 & 2.3 \\
\hline Turkey & 2352.4 & 93.4 & 5.0 \\
\hline Hungary & 1646.3 & 124.1 & 3.5 \\
\hline Czech & 878.1 & 122.8 & 1.9 \\
\hline EU countries & 20158.5 & 115.0 & 42.6 \\
\hline
\end{tabular}

In 2018, Ukraine conducted foreign trade operations with partners from 221 countries of the world who acquired changes in the product and quantitative structure of foreign trade relations (Table 2). In 2018, the volume of Ukrainian exports to EU countries (28 countries) amounted to $23,032 \mathrm{mln}$ doll. USA, which is $14.3 \%$ higher than the previous year. Imports from EU countries (28 countries) in 2018 amounted to 26,2851 mln doll. USA, which is $12.7 \%$ higher than in the corresponding period of the previous year.

In bilateral trade, a balance was maintained (Figure 1). 
The found polynomial regression function (1) indicates a general negative trend between exports and imports for the EU countries.

The same trend persists for most of the studied EU countries (1).

$$
y=19,953 x^{2}-370,23 x+607,77, R^{2}=0,55
$$

Table 2. The main trading partners in import of Ukraine in 2018 [24].

\begin{tabular}{|c|c|c|c|}
\hline Countries & million dollars & \% to 2017 & $\begin{array}{c}\text { \% to common } \\
\text { volume }\end{array}$ \\
\hline Total, including: & 57141.0 & 115.2 & 100.0 \\
\hline Belarus & 3787.0 & 118.1 & 6.6 \\
\hline Egypt & 96.8 & 125.6 & 0.2 \\
\hline India & 616.6 & 109.9 & 1.1 \\
\hline Spain & 629.1 & 108.7 & 1.1 \\
\hline Italy & 2031.1 & 125.0 & 3.6 \\
\hline China & 7604.0 & 134.6 & 13.3 \\
\hline Republic Moldova & 118.1 & 110.6 & 0.2 \\
\hline Netherlands & 776.4 & 120.6 & 1.4 \\
\hline Germany & 5983.2 & 109.9 & 10.5 \\
\hline Poland & 3634.6 & 105.2 & 6.4 \\
\hline Russian Federation & 8092.7 & 112.3 & 14.2 \\
\hline Romania & 511.1 & 111.6 & 0.9 \\
\hline Saudi Arabia & 186.8 & 102.1 & 0,3 \\
\hline Slovakia & 525.7 & 103.3 & 0.9 \\
\hline USA & 2962.3 & 117.3 & 5.2 \\
\hline Turkey & 1714.2 & 135.8 & 3.0 \\
\hline Hungary & 1267.8 & 110.0 & 2.2 \\
\hline Czech & 1035.6 & 119.1 & 1.8 \\
\hline EU countries & 23182.8 & 111.5 & 40.6 \\
\hline
\end{tabular}

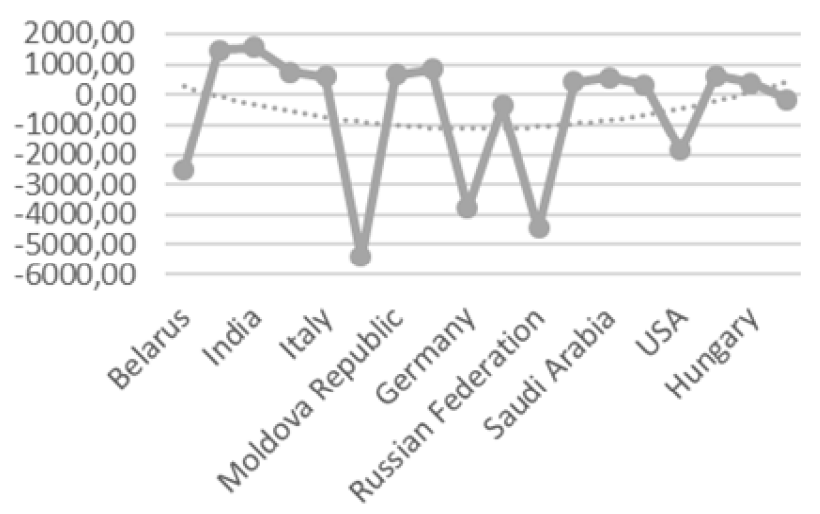

Fig. 1. Export-import balance of the main trading partners of Ukraine in 2018 (in mln doll. USA) [24].

According to statistic [24], the volume of trade between Ukraine and the countries of the EU increased by $55 \%$. In 2018, the EU bought more Ukrainian goods than during all the time of bilateral cooperation. As for the Russian Federation, in comparison with the data of 2017 , it is worth noting that the export of goods decreased by $7.7 \%$, while imports fell by $14.2 \%$. The export of Ukrainian products to the EU has reached record volumes in history and is growing rapidly, but the potential for economic integration is far from proper use. And then it is growing dynamically: over the eight months of 2018 it grew by $18.6 \%$.

And its share in total Ukrainian exports is from $40 \%$ to $42.1 \%$. In 12 out of 25 regions controlled by Ukraine, the share of exports to the EU ranges from 50\% to $90 \%$. Moreover, among them are not only traditionally Eurooriented west, but also Donetsk and Lugansk regions, where the share of exports to the EU also reaches $50 \%$ of the total export and is higher than in some regions of Central Ukraine.

\section{Conclusion}

In order to ensure stable economic development of Ukraine, it should be noted that European integration is a strategic goal of the Ukrainian state, enshrined in law. The analysis of positive and negative consequences made it possible to assess Ukraine's potential with the potential use of the positive aspects of European integration and at the same time developing an action program for the painless integration of Ukraine, taking into account the existing threats and experience of countries that have recently become EU members.

At the moment, there are several arguments in favour of developing mutual cooperation between our country and the EU with a view to sustainable development and taking into account the characteristics of the Ukrainian economy:

1. The European Union is a large market, as well as a good market for importing products.

2. Trade with the EU is an important source of currency. 3. Production technology. Ukrainian enterprises lag behind their counterparts in advanced European countries, our country does not have the capital necessary to modernize existing and create new modern enterprises. Without modernization of production structures in Ukraine, it is unlikely that it can leave the path of sustainable economic development and overcome the growing lag behind economically developed countries. Access to the EU market, in turn, will open access to Ukraine to foreign investors and capital.

4. Access to the European market of Ukrainian enterprises is of great importance as a source of experience and practical skills in order to compete with manufacturers in other countries.

5. The development of cooperation with the EU will contribute to more efficient use of the potential of Ukraine as a transit state, which means an increase in revenues from the export of transport services and the development of related industries.

We can conclude that, given the influence of integration factors on the political, economic and social spheres of the state, Ukraine's entry into the European Union remains much more promising. Seeking stable development, positive changes are expected in the development of the Ukrainian economy, which will take place as a result of European integration. The cooperation of Ukraine with the EU will help bring closer social conditions of Ukraine with high European standards, increase living standards and well-being of the population. Membership in the EU guarantees the strengthening of national security of Ukraine and its protection from aggression and territorial claims. 


\section{References}

1. General Assembly of the United Nations (2019), https://www.un.org/en/ga. Accessed 23 Oct 2019

2. United Nations Development Program (2019), https://www.undp.org/content/undp/en/home. Accessed 15 Oct 2019

3. I. Erauskin, S. Turnovsky, International financial integration and income inequality in a stochastically growing economy. J. of Int. Ec. 119, 55-74 (2019). doi:10.1016/j.jinteco.2019.04.003

4. N. Kuprina, Kh. Baraniuk, K. Vaskovska, Competitiveness of the national economy: current aspects of management. Periodicals of Engineering and Natural Sciences 7(2), 794-805 (2019). doi:10.25140/2410-9576-2017-1-2(10)-24-34

5. S. Yakubovskiy, T. Rodionova, A. Kyfak, Inflow of Foreign Capital as a Factor of the Development of Current Accounts of the Eastern European Countries. J. Trans. St. Rev. 26(2), 3-14 (2019). doi:10.14665/1614-4007-26-001

6. T. Rodionova, S. Yakubovskiy, A. Kyfak, Foreign Capital Flows as Factors of Economic Growth in Bulgaria, Czech Republic, Hungary and Poland. Res. in World Ec. 10(4), 48-57 (2019). doi:10.5430/rwe.v10n4p48

7. A.P. Holikov, International economic relations (KhNU im. V.N. Karazina, Kharkiv, 2015)

8. V. Babenko, Z. Kulczyk, I. Perevosova, O. Syniavska, O. Davydova, Factors of the development of international e-commerce under the conditions of globalization. SHS Web of Conf. 65, 10-16 (2019). doi:10.1051/shsconf/20196504016

9. O.I. Pursky, B.V. Grynyuk, D.A. Shestopal, Planning of advertising costs and vendor number at e-trade market, Actual Problems of Economics 177(3), 407-413 (2016)

10. A. Enders, Z. Enders, M. Hoffmann, International financial market integration, asset compositions, and the falling exchange rate pass-through. J. of Int. Ec. 110, 151-175 (2018). doi:10.1016/j.jinteco.2017.11.002

11. A.R. Alotaibi, A.V. Mishra, Time varying international financial integration for GCC stock markets. The Quart. Rev. of Ec. and Fin. 63, 66-78 (2017). doi:10.1016/j.qref.2016.03.001

12. S. Didenko, Record volume with EU and decrease in share with Russia: with whom and how Ukraine traded in 2018 (2018), https://ua.news/ua. Accessed 17 Sep 2019

13. O.S. Kvasha, A.V. Synyakova, Ukraine and the EU: problems and prospects for integration in today's context. Sc. Bull. of Uzhgorod Nat. Un. 23, 112-117 (2019)

14. S.V. Marynina, The essence, problems and prospects of development of forms of international economic integration. For. Trade: Ec., Fin., Law. 56, 40-46 (2014)
15. M.I. Nazarov, The current state of integration processes in the world. Ekonomika i suspil'stvo 18, 57-64 (2018)

16. O.O. Reznikova, Ukraine in Regional Integration Processes: Rationale for Choice. Fin. of Ukr., 6, 5361 (2015)

17. V. Babenko, I. Perevozova, O. Mandych, T. Kvyatko, O. Maliy, I. Mykolenko, World informatization in conditions of international globalization: Factors of influence. Gl. J. of Env. Sci. and Man. 5(SI), 172-179 (2019). doi:10.22034/gjesm.2019.05.SI.19

18. T.V. Shcherbyna, Theories of regional economic integration in the context of international relations development. Probl. and prosp. of dev. of bank. of Ukr. 38, 306-314 (2014)

19. L. Malyarets, M. Draskovic, V. Babenko, Z. Kochuyeva, O. Dorokhov, Theory and practice of controlling at enterprises in international business. Ec. Annals-XXI 165(5-6), 90-96 (2017). doi:10.21003/ea.V165-19

20. Global Innovation Exchange (2019), https://www.globalinnovationexchange.org. Accessed 3 Sept 2019

21. O. Pursky, T. Dubovyk, I. Moroz, I. Buchatska, A. Savchuk, The price competition simulation at the blended trading market. CEUR Workshop Proceedings 2422, 15-26 (2019). http://ceurws.org/Vol-2422/paper02.pdf. Accessed 3 Feb 2019

22. Ukraine-EU trade and economic cooperation (2019), https://ukraine-eu.mfa.gov.ua. Accessed 20 Oct 2019

23. Ukraine on the Road to the EU: Citizens' Assessments, Opinions and Expectations (2019), http://razumkov.org.ua. Accessed 11 Oct 2019

24. State Statistics Service of Ukraine (2019), www.ukrstat.gov.ua. Accessed 7 Oct 2019 